\title{
Питання психології
}

УДК 159.944

DOI: $10.33099 / 2617-6858-21-63-5-27-34$
Войтенко О. В. кандидат психологічних наук, дочент, доцент кафедри психології, Київський національний торговельно-економічний університет

https://orcid.org/0000-0002-9407-4574

\section{ЗАЛУЧЕНІСТЬ ПЕРСОНАЛУ ОРГАНІЗАЦІЙ: ОСНОВНІ ПІДХОДИ, ЧИННИКИ ФОРМУВАННЯ ТА ПРАКТИЧНЕ ЗНАЧЕННЯ}

Метою статті є теоретичний аналіз основних підходів, базових принципів та особливостей формування залученості персоналу в діяльність організації. Для реалізаиії поставленої мети вирімено низку завдань: розкрито зміст поняття залученість персоналу, проаналізовано різні підходи до ї̈ вивчення; виділено фактори, щя визначають рівень залученості персоналу й оптимальні умови цілеспрямованого формування залученості персоналу організації.

Ключові слова: персонал організацій; залученість персоналу; рівень залученості; фактори впливу на формування залученості.

Вступ. У конкурентних умовах ринкової економіки зростає роль управління залученням персоналу в робочі процеси організації. Компанії потребують працівників, які швидко реагують на зміни, неформально ставляться до роботи, ефективно справляються 3 поставленими завданнями.

Залученість на робочому місці зазвичай розглядається як позитивний, такий, що приносить задоволення, емоційномотиваційний стан благополуччя, пов'язаного з роботою (Macey \& Schneider, 2008) [1].

Попередні дослідження показали, що залученість на робочому місці позитивно впливає на результати роботи, такі як продуктивність як на організаційному, так i на індивідуальному рівні. Показано взаємозв'язок між залученістю в роботу і іiі продуктивністю (Bakker, 2011) [2]. Навпаки, наявність в організації великого числа співробітників, що характеризуються низьким ступенем залученості у справи i зацікавленості в успіху, буде проявлятися, перш за все, у високих показниках плинності кадрів, прихованого відтоку, пропусків роботи через хворобу, в недотриманні термінів виконання завдань, відсутності ініціативи, інтересу до передачі досвіду і підвищення кваліфікації та ін. (Масілова і Бурцева) [3]. Іншими словами, організації потребують залучених співробітників, які зацікавлені в іiі успішності. Саме тому залученість персоналу стає важливим об'єктом управлінської діяльності і предметом дослідження в різних аспектах.

Метою статті $\epsilon$ теоретичний аналіз основних підходів, базових принципів та особливостей формування залученості персоналу в діяльність організації. Реалізація поставленої мети передбачає вирішення низки завдань, як-от: 1) розкриття змісту поняття залученість персоналу, аналіз різних підходів до іiі вивчення та ознак іiї прояву; 2) дослідження факторів, що визначають рівень залученості персоналу й 3) визначення оптимальних умов цілеспрямованого формування залученості персоналу організації.

теоретичне підгрунтя. Згідно сучасних досліджень, залученість персоналу $€$ багатогранним конструктом і визначається по-різному. Термін залученість одним 3 перших описав Вільям Кан (1990) [4]. Він визначив залученість як причетність співробітників організації до власних робочих ролей. У залученості автор виділяв когнітивний аспект, під яким розумів думку співробітників про організацію, іiі лідерів (керівників) і умови праці, емоційний аспект - позитивне або негативне ставлення до організації та іiї керівників, фізичний аспект - енергію, яку вкладають співробітники у виконання своєї роботи.

Христина Маслач i Майкл Лейтер (1997) запропонували принципово інший підхід до трактування залученості. Згідно їхньої думки, залучення персоналу має визначатися не як окремий конструкт, а як позитивна протилежність професійному 


\section{Питання психології}

вигоранню. При цьому в якості компонентів залученості розглядаються: високий рівень енергії, захопленість, відчуття ефективності [5]. Показано також, що персонал організацій здатний працювати тривалий час, не вигораючи (Войтенко та ін., 2021) [6]. Багато фахівців 3 великим стажем роботи, довгі роки перебуваючи в стресогенних умовах, продовжують і далі продуктивно працювати, реалізовуючи себе в діяльності, вважаючи, що професійна діяльність для них наділена змістом, вони відчувають залученість в діяльність без ознак професійного вигорання. Резистентність до вигорання обумовлюється залученістю в професію, в основі якої лежать особливості ціннісно-смислової сфери особистості, а саме можливість самоактуалізації. (Войтенко та ін., 2021) [7].

Надалі основний акцент при розгляді феномена залученості зміщується на більш поглиблене вивчення прихильності організації і трудового ентузіазму. Залученість працівників визначається вже як емоційна i iнтелектуальна прихильність організації, а також кількість тих зусиль, які співробітник може проявити в роботі. Так, наприклад, К. Трусс i iн. визначають залученість просто як «пристрасть до роботи» (Truss et al., 2006) [8, с. 95]. O. Знаменський визначає залученість персоналу як емоційний та інтелектуальний стан працівників, при якому вони проявляють наднормативну активність прагнуть виконувати роботу якнайкраще, як правило, не вимагаючи за це окремої оплати (Знаменський, 2015) [9].

Особливістю іншого підходу $\epsilon$ розуміння залученості як особливого виду мотивації до досягнення цілей підприємства i прояв в основних аспектах трудової діяльності працівників: виконанні своїх функцій, поліпшенні соціально-економічних результатів, участь у розробці та реалізації стратегії розвитку компанії. Залученість - це спонукання людини до праці, що $\epsilon$ наслідком внутрішніх спонукальних елементів, таких як потреби, інтереси, ціннісні орієнтири, з одного боку, з іншого що відображаються і фіксуються свідомістю людини фактори зовнішнього середовища, тобто зовнішні стимули, які спонукають до діяльності (Базарова і Єрьоміна, 2012) [10]. Тобто діяльність працівника - та ознака, яка може об'єктивно охарактеризувати залученість. Залучені співробітники відчувають більше позитивних емоцій, виявляють оптимізм і більше ентузіазму в роботі (Bakker, 2011) [2]. Крім того, вони можуть краще використовувати свої особисті ресурси (самоактуалізація); мати краще здоров'я; i здатні передавати залученість іншим співробітникам в їх робочому середовищі (Ferreira et al., 2020) [11].

Дослідники також часто розглядають залучення персоналу в контексті організаційної культури компанії (Масілова і Бурцева, 2016) [3], механізмів ціннісного управління персоналом (Іванова i Зоріна, 2016) [12]. Л. В. Щетініна та А. Є. Яструбинська пропонують трактувати залученість як процес, за якого співробітники приймають участь у прийнятті управлінських рішень в організації, що забезпечує їх вплив на діяльність організації [13]. Лозовський О.М. і Зайцева Д.Є визначають залученість (engagement) персоналу як комплексний показник, який характеризує стан корпоративної культури компанії та потенціал іiі розвитку за рахунок того, наскільки небайдуже працівники ставляться до своїх трудових обов'язків та організації загалом [14]. Залученість співробітника полягає в відношенні його до компанії, іiі керівництва, своїх виконуваних обов'язків i умов праці, що виражається в прояві щирого інтересу до успіхів компанії і прагненні виконувати свої обов'язки, перевершуючи встановлені стандарти, регламент (Хеллевиг, 2012) [15]. Залученість характеризує взаємовідносини у системі «організація-працівник». При цьому працівник готовий до виконання дій, що можуть виходити за межі його прямих обов'язків, докладати додаткові зусилля, рекомендувати свою компанію як надійного роботодавця, а також працювати в компанії якомога довше (Коновалова, 2014) [16]. Залучені працівники зацікавлені в успіху організації; задоволені змістом праці; бачать перспективу особистого i професійного зростання; створюють в колективі здорову робочу атмосферу, приймають і розділяють організаційні цінності. На основі проведеного аналізу можна виділити кілька основних підходів до розуміння залученості персоналу організацій (таблиця 1). 


\section{Питання психології}

3'ясовано, що істотний вплив на залученість співробітників в роботу надають стилі керівництва. Так, показано, що, зокрема, трансформаційне i транзакційне лідерство мають більшу здатність прогнозувати психологічний капітал співробітників і їх залученість в роботу; психологічний капітал співробітників діє як частковий посередник між стилями керівництва i залученістю співробітників у роботу ( $\mathrm{Li}$ et all, 2018) [18]. О.М. Лозовський і Д.Є. Зайцева (2017) серед драйверів залучення персоналу виокремлюють можливість кар' єрного зростання, умови для навчання та розвитку, внутрішні комунікації, компенсації та бонуси, збігання мети діяльності організації 3 особистими життєвими планами тощо. Однак ці автори також визнають ключовим фактором впливу на зацікавленість персоналу трансформаційне лідерство, що дозволяє менеджерам об'єктивно оцінювати можливості та потенціал своїх команд $\mathrm{i}$ ставити перед їх учасниками достатньо амбіційні, але при цьому досяжні цілі; спонукати співробітників дотримуватися робочої етики та високих стандартів ведення бізнесу на своєму прикладі, а також показувати працівникові, яку цінність мають його дії для всієї організації [14].

В інших дослідженнях показано, що парадоксальна (амбідекстерна) лідерська поведінка позитивно пов'язана 3 ясністю цілей $\mathrm{i}$ автономією роботи $\mathrm{i}$ надає опосередкований вплив на залученість в роботі через ці змінні (Fürstenberg, Alfes, and Kearney, E., 2021) [19]. Більш того, результати цього дослідження підтверджують гіпотетичний ефект взаємодії ясності мети i автономності роботи для прогнозування залученості підлеглих у роботу, а також умовний непрямий вплив амбідекстерної лідерської поведінки на залученість через інтерактивний ефект. Щоб ефективно залучати підлеглих у свою роботу, лідери повинні створювати робоче середовище, в якому підлеглі точно знають, що їм робити (тобто мають високу ясність мети), але в той же час можуть самостійно визначати, як виконувати свою роботу (тобто мати автономність роботи.
Існує дослідження взаємозв'язку між існуванням ефективних систем розвитку персоналу та підвищенням рівня його залученості, яке виявило високий ступінь залежності між наявністю перспектив професійного зростання, можливістю вдосконалювати свої навички на робочому місці та бажанням продовжувати роботу на підприємстві, уособленням власних i корпоративних завдань (Бей, 2018). На основі результатів соціологічного дослідження цим автором був зроблений розподіл чинників впливу на рівень залученості персоналу, згідно якого $31 \%$ займає система нарахування та виплати винагород; $22 \%$ - кадрова політика, розвиток і просування; $17 \%$ - внутрішня політика компанії; $10 \%$ - морально психологічний клімат; $10 \%$ - зміст праці; $5 \%$ - корпоративна культура і $5 \%$ умови праці. Як видно з цього розподілу максимальний рівень залученості характеризується системою винагород та нарахування виплат, тобто зовнішніми чинниками мотивації [20].

Показано також зв'язок кар'єрної адаптованості 3 багатьма результатами роботи і життя, включаючи залученість у роботу (Rossier, et al., 2012) [21]. Дослідження динаміки рівня залученості в залежності від стажу роботи показали спад загального рівня залученості персоналу, який пропрацював в організації менше 1 року, що пов'язано, на думку автора, 3 недостатньою кар'єрною адаптованістю (Якімова \& Пушкіна, 2018) [22]. Однак, конкретних досліджень впливу адаптованості на залученість недостатньо. Залишається невідомим характер зв'язку між ними i способами, якими адаптованість впливає на залучення співробітників. Цілком можливо, що вплив кар'єрної адаптованості на залученість може бути опосередковано певними факторами, наприклад, мотивацією. Теорія самодетермінації розрізняє внутрішню мотивацію (тобто виконання дяльності заради самого себе, тому що діяльність за своєю суттю є цікавою і задовільною) i зовнішню мотивацію (тобто виконання діяльності 3 інструментальних причин) (Deci \& Ryan, 2002) [23]. Автори стверджують, що дії, які не сприймаються як цікаві, оптимально складні або естетично приємні, наприклад, робота, 


\section{Питання психології}

навряд чи будуть виконуватися, якщо відсутня зовнішня причина для їх виконання. Як правило, недостатньо лише зовнішнього впливу на індивіда. Роботодавцю необхідно створити умови для внутрішньої мотивації, яка регулює поведінку всередині самої особистості. При компетентному менеджменті дані умови можуть забезпечити підвищення залученості, дозволяючи досягати високих фінансових показників організації та загальної ефективності праці. М.Г. Масилова і Ю.В. Бурцева як чинники, що повинні виступати предметом вивчення при дослідженні залученості, виділили ставлення до керівництва організації i безпосереднього керівника; можливість брати участь в управлінні, впливати на рішення, що приймаються, а також інформованість про події і плани; впевненість в тому, що співробітники важливі організації; прийняття працівниками організаційних цілей i цінностей; задоволеність організацією роботи (Масілова і Бурцева, 2016) [3].

Можна систематизувати основні чинники впливу на показники залученості персоналу організацій наступним чином (таблиця 2):

Фактори впливу на показники залученості персоналу

\begin{tabular}{|l|l|}
\hline \multicolumn{1}{|c|}{ Зовнішні (організаційні) фактори } & \multicolumn{1}{c|}{ Внутрішні (особистісні) фактори } \\
\hline стиль лідерства & кар'єрна адаптованість \\
\hline організаційна культура & впевненість у власній цінності для організації \\
\hline ефективні канали комунікацій & прийняття організаційних цілей і цінностей \\
\hline $\begin{array}{l}\text { можливість розвитку і перспектива кар'єрного } \\
\text { зростання }\end{array}$ & самоактуалізація \\
\hline ясність цілі та автономність роботи & внутрішня мотивація \\
\hline система винагород та нарахування виплат & $\begin{array}{l}\text { позитивне ставлення до діяльності організації } \\
\text { та її керівництва }\end{array}$ \\
\hline
\end{tabular}

Можна бачити, що дані фактори

одночасно $\epsilon$ показниками, що характеризують окремі аспекти менеджменту в організації та їх наслідки. Співробітники емоційно i когнітивно залучені, коли вони знають, чого від них чекають, мають все необхідне для виконання роботи, відчувають вплив i задоволення у своїй роботі, усвідомлюють, що вони $є$ частиною чогось значного, $\mathrm{i}$ мають можливість вдосконалюватися i розвиватися, тобто основою формування залученості виступають, в першу чергу, зовнішні (організаційні) и внутрішні, (особистісні) фактори, пов'язані 3 особливостями ціннісно-смислової сфери, iз вмістом професії (цінностями, рівнем самоактуалізації).

Висновки. Залученість персоналу в робочі процеси видається сьогодні найважливішою умовою ефективного функціонування організацій різних видів діяльності. Тому підвищення залученості персоналу в роботу організації стає найважливішим завданням будь-якого керівника. Узагальнюючи проаналізовані дані, можна визначити залученість як якісну характеристику персоналу, яка містить позитивне ставлення до діяльності організації та іii керівництва, розуміння значущості свого вкладу в розвиток організації, прагнення зростати разом 3 організацією через прояв ініціативи та внесення інновацій, конструктивний діалог на рівні керівник-підлеглий, що передбачає делегування повноважень та взаємну підтримку. При такому ставленні до компанії i ii керівництва людина проявляє ініціативу і мобілізує весь свій потенціал i приховані резерви для вирішення поставленого завдання, поліпшення роботи компанії, досягнення іiі стратегічних i тактичних цілей. Можна бачити, що дані фактори одночасно $\epsilon$ показниками, що характеризують окремі сторони менеджменту в організації. Тому у подальшому представлясться перспективним дослідження безпосереднього впливу характеру лідерства на залученість, а також розробка психологічної моделі залучення персоналу організації в іiї робочі процеси. 


\section{Питання психології}

\section{Список використаних джерел:}

1. Macey W., Schneider B. Engaged in Engagement: We are delighted we did it. Industrial and Organizational psychology. 2008. № 1. 76-83.

2. Bakker A.B. An evidence-based model of work engagement. Current Directions in Psychological Science, 2011. V. 20 № 4. P. 265-269.

3. Масилова М.Г., Бурцева Ю.В. Вовлеченность персонала как характеристика организационной культуры. Территория новых возможностей. Вестник Владивостокского государственного университета экономики и сервиса. 2016. № 3. С. 137-145.

4. Kahn W.A. Psychological Conditions of Personal Engagement and Disengagement at Work. Academy of Management Journal. 1990 V. 33 №4. P. 692-724.

5. Maslach C., Leiter M.P. The Truth About Burnout: How Organizations Cause Personal Stress and What to do About it. San Francisco, CA: Jossey-Bass, 1997. 202 p.

6. Voitenko E., Myronets S., Osodlo V., Kushnirenko K., Kalenychenko R. Influence of Emotional Burnout on Coping Behavior in Pedagogical Activity. International journal of organizational leadership. 2021. V.10. № 2, P. 183-196

7. Voitenko E., Kaposloz H., Myronets S., Zazymko O., Osodlo V. Influence of characteristics of self-actualization and coping behavior on resistance of teachers to professional stressors and emotional burnout. International journal of organizational leadership. 2021. V. 10. № 1. P.1-14.

8. Truss C. Working Life: Employee Attitudes and Engagement / Truss C., Soane E., Edwards C., Wisdom K., Croll A. and Burnett J. London: CIPD, 2006. 112 p.

9. Знаменский А. Вовлеченность - миф или реальность. Управление персоналом. 2015. № 2. C. $41-46$.

10. Базарова Т.Ю., Ерёмина Б.Л. Управление персоналом: учебник для вузов. Москва: Юнити-Дана, 2012. 273 с.

11. Ferreira P., Gabriel C., Faria S., Rodrigues P., Sousa Pereira M. What if employees brought their life to work? The relation of life satisfaction and work engagement. Sustainability. 2020. 12(7), P. 27-43.

12. Иванова Т.Н., Зорина К.Х. Изменения в практике управления персоналом современных организаций. Карельский научный журнал. 2016. Т. 5. № 3 (16). С. 125-128.

13. Щетініна Л.В., Яструбинська А.С. Оцінювання залученості персоналу: значення, вимоги та практичні рекомендації. 2017. C. 259-266. URL: http://ir.kneu.edu.ua/bitstream/2010/22607/3/259266.pdf

14. Лозовский А.Н., Зайцева Д.Е. Підвищення економічного потенціалу підприємств шляхом імплементації програми енгейджменту. Економіка і суспільство. 2017. Вип. 13. С.572-577.

15. Хеллевиг Й. Вовлеченность персонала в России. Предварительная версия. М. : Гайд Авара, 2012. 118 с.

16. Коновалова В. Управление вовлеченностью персонала: факторы успехов и неудач. Кадровик. 2014. № 9. С 74- 84

17. Kular S., Gatenby M., Rees C., Soane E., Truss K. Employee engagement: a literature review. London, GB. : The Chartered Institute of Personnel and Development, 2008. URL: http://eprints.soton.ac.uk/id/eprint/336292

18. Li Y., Castaño G., Li Y. Linking leadership styles to work engagement: The role of psychological capital among Chinese knowledge workers. Chinese Management Studies. 2018. Vol. 12. №. 2, P. 433-452. https://doi.org/10.1108/CMS-04-2017-0108

19. Fürstenberg N., Alfes K., Kearney E. How and when paradoxical leadership benefits work engagement: The role of goal clarity and work autonomy. Journal of Occupational and Organizational Psychology. 2021. V. 94. № 3. P. 672-705. URL: https://doi.org/10.1111/joop.12344

20. Бей Г.В. Управління розвитком персоналу як метод забезпечення високого рівня залученості працівників. Modern Economics. 2018. № 8. C.6-14. URL: https://modecon.mnau.edu.ua/issue/8-2018/UKR/bei.pdf

21. Rossier J., Zecca G., Stauffer S. D., Maggiori C., Dauwalder J. P. Career adaptabilities scale in a French-speaking Swiss sample: Psychometric properties and relationships to personality and work engagement. Journal of Vocational Behavior. 2012. № 80, P. 734-743.

22. Якимова 3.В., Пушкина А.С. Динамика уровня вовлеченности персонала в зависимости от стажа работы в организации. Азимут научных исследований: экономика и управление. 2018. Т. 7. № 1(22), C.283-286.

23. Deci E.L., Ryan, R.M. Handbook of self-determination research. Rochester, NY: University of Rochester Press, 2002. 480 p. 


\section{Питання психології}

\section{References}

1. Macey, W, \& Schneider, B. (2008). Engaged in Engagement: We are delighted we did it. Industrial and Organizational psychology, 1, 76-83.

2. Bakker, A.B. (2011). An evidence-based model of work engagement. Current Directions in Psychological Science, 20(4). 265- 269.

3. Masilova M.G., Burtceva Iu.V. (2016). Vovlechennost personala kak kharakteristika organizatcionnoi kultury [Personnel involvement as a characteristic of organizational culture]. Territoriia novykh vozmozhnostei. Vestnik Vladivostokskogo gosudarstvennogo universiteta ekonomiki i servisa Territory of new opportunities. Bulletin of the Vladivostok State University of Economics and Service, 3, 137-145 [in Russian].

4. Kahn, W.A. (1990). Psychological Conditions of Personal Engagement and Disengagement at Work. Academy of Management Journal, 33(4). 692-724.

5. Maslach, C., Leiter, M.P. (1997). The Truth About Burnout: How Organizations Cause Personal Stress and What to do About it. San Francisco, CA: Jossey-Bass.

6. Voitenko, E., Myronets, S., Osodlo, V., Kushnirenko, K., Kalenychenko, R. (2021). Influence of Emotional Burnout on Coping Behavior in Pedagogical Activity. International journal of organizational leadership, 10 (2), 183-196.

7. Voitenko, E., Kaposloz, H., Myronets, S., Zazymko, O., Osodlo, V. (2021). Influence of characteristics of self-actualization and coping behavior on resistance of teachers to professional stressors and emotional burnout. International journal of organizational leadership, 10 (1), 1-14.

8. Truss, C., Soane, E., Edwards, C., Wisdom, K., Croll A. and Burnett, J. (2006). Working Life: Employee Attitudes and Engagement. London: CIPD.

9. Znamenskii, A. (2015). Vovlechennost - mif ili realnost [Involvement - myth or reality]. Upravlenie personalom. - Personnel Management, 2, 41-46 (in Russian).

10. Bazarova, T.Iu., Eremina, B.L. (2012). Upravlenie personalom: uchebnik dlia vuzov [Personnel management: a textbook for universities]. Moskva: Iuniti-Dana (in Russian).

11. Ferreira, P., Gabriel, C., Faria, S., Rodrigues, P., \& Sousa Pereira, M. (2020). What if employees brought their life to work? The relation of life satisfaction and work engagement. Sustainability, 12(7), 27-43.

12. Ivanova, T.N., Zorina, K.Kh. (2016). Izmeneniia $\mathrm{v}$ praktike upravleniia personalom sovremennykh organizatcii [Changes in the practice of personnel management in modern organizations]. Karelskii nauchnyi zhurnal - Karelian scientific journal, 5(3/16), 125-128 (in Russian).

13. Shchetinina, L.V., Iastrubinska, A. E. (2017). Otciniuvannia zaluchenosti personalu: znachennia, vimogi ta praktichni rekomendatciï [Estimation of personnel involvement: meaning, requirements and practical recommendations]. Retrieved from http://ir.kneu.edu.ua/bitstream/2010/22607/3/259-266.pdf (in Ukrainian).

14. Lozovskii, A.N., Zaitceva, D.E. (2017). Pidvishchennia ekonomichnogo potentcialu pidpriemstv shliakhom implementatciï programi engeidzhmentu [Increasing the economic potential of enterprises through the implementation of the engagement program]. Ekonomika i suspilstvo - Economy and Society, 13, 572-577 (in Ukrainian).

15. Khellevig, I. (2012). Vovlechennost personala v Rossii. Predvaritelnaia versiia [Personnel involvement in Russia. Preliminary version]. Moskva: Gaid Avarac (in Russian).

16. Konovalova, V. (2014). Upravlenie vovlechennostiu personala: faktory uspekhov i neudach [Personnel engagement management: factors of success and failure]. Kadrovik-Kadrovik, 9, 74- 84 (in Russian).

17. Kular, S., Gatenby, M., Rees, C., Soane, E., Truss, K. (2008). Employee engagement: a literature review. London, GB: The Chartered Institute of Personnel and Development Retrieved from http://eprints.soton.ac.uk/id/eprint/336292

18. Li, Y., Castaño, G., Li, Y. (2018). Linking leadership styles to work engagement: The role of psychological capital among Chinese knowledge workers. Chinese Management Studies, 12 (2), 433-452. Retrieved from https://doi.org/10.1108/CMS-04-2017-0108

19. Fürstenberg, N., Alfes, K., Kearney, E. (2021), How and when paradoxical leadership benefits work engagement: The role of goal clarity and work autonomy. Journal of Occupational and Organizational Psychology. 94. (3). 672-705. Retrieved from https://doi.org/10.1111/joop.12344

20. Bei, G.V. (2018). Upravlinnia rozvitkom personalu iak metod zabezpechennia visokogo rivnia zaluchenosti pratcivnikiv [Management of personnel development as a method of ensuring a high level of employee involvement]. Modern Economics - Modern Economics, 8, 6-14 [in Ukrainian]. Retrieved from https://modecon.mnau.edu.ua/issue/8-2018/UKR/bei.pdf 


\section{Питання психології}

21. Rossier, J., Zecca, G., Stauffer, S. D., Maggiori, C., \& Dauwalder, J. P. (2012). Career adaptabilities scale in a French-speaking Swiss sample: Psychometric properties and relationships to personality and work engagement. Journal of Vocational Behavior, 80, 734-743.

22. Iakimova Z.V., Pushkina A.S. (2018). Dinamika urovnia vovlechennosti personala v zavisimosti ot stazha raboty $\mathrm{v}$ organizatcii [Dynamics of the level of personnel involvement depending on the length of service in the organization.]. Azimut nauchnykh issledovanii: ekonomika i upravlenie Research Azimuth: Economics and Management, 7, (1/22), 283-286 (in Russian).

23. Deci, E. L., Ryan, R. M. (2002). Handbook of self-determination research. Rochester, NY: University of Rochester Press.

\section{Резюме}

Войтенко Е. кандидат психологических наук, доцент, Киевский национальныий торгово-экономический университет

\section{ВОВЛЕЧЕННОСТЬ ПЕРСОНАЛА ОРГАНИЗАЦИЙ: ОСНОВНЫЕ ПОДХОДЫ,} ПРИЧИНЫ ФОРМИРОВАНИЯ И ПРАКТИЧЕСКОЕ ЗНАЧЕНИЕ

Цель статьи - представить результаты теоретического анализа основных подходов, базовых приниипов и особенностей формирования вовлеченности сотрудников в деятельность организачии. Раскрывается содержание понятия вовлеченность персонала, анализируются разные подходы к ее изучению, выделены факторы, определяющие уровень вовлеченности персонала и оптимальные условия целенаправленного формирования вовлечённости персонала в организации.

Ключевые слова: персонал организаций; вовлеченность персонала; уровень вовлеченности; факторы влияния на формирование вовлеченности.

\section{Summary \\ Voitenko E. PhD in Psychology, Associate Professor at Department of Psychology, Kyiv national university of trade and economics \\ EMPLOYEE ENGAGEMENT IN ORGANIZATIONS: MAIN APPROACHES, FORMATION FACTORS AND PRACTICAL SIGNIFICANCE}

Introduction. In a competitive market economy, the role of managing an employee engagement in the work processes of the organization is growing. Companies need employees who respond quickly to change, have an informal attitude to work, and effectively cope with the tasks.

Purpose. of the article is a theoretical analysis of the main approaches, basic principles and features of the formation of staff engagement in the organization. Realization of the set purpose provides the decision of a number of tasks, such as: 1) disclosure of the maintenance of staff engagement concept, the analysis of various approaches to its studying and signs of its display; 2) study of the factors that determine the level of staff engagement and 3) determination of the optimal conditions for the purposeful formation of employee engagement of the organization.

Methods. The specificity of the purpose of the study determined the feasibility of using a set of general scientific theoretical methods, in particular the analysis and generalization of scientific data.

Originality. The article considers engagement as a qualitative characteristic of staff, which contains a positive attitude to the organization and its management, understanding the importance of their contribution to the organization, the desire to grow with the organization through initiative and innovation, constructive dialogue at the managerial level, providing for delegation of authority and mutual support. The author's contribution is to generalize and systematize modern ideas about the engagement of staff of organizations, as well as the conditions for increasing the level of engagement in organization.

Conclusion. The article emphasizes that the engagement of staff in work processes seems to be the most important condition for the effective functioning of organizations of various activities. Therefore, increasing the engagement of staff in the work of the organization becomes the most important task of any manager. Formation and development of the concept of staff engagement can be traced back to the end of the XX century. The current stage of research on the phenomenon of engagement is characterized by the search for ways to effectively manage human resources, as well as improving the practice of staff engagement.

Key words: staff engagement, level of engagement, factors influencing the formation of engagement.

Recelved/Поступила: 17.11.21. 